OAJIS

Journal of

Information

Systems

is.its.ac.id/pubs/oajis/

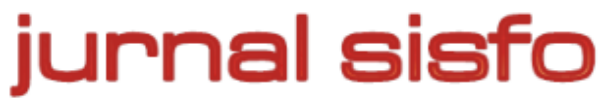

Jurnal Sisfo Vol. 07 No. 01 (2017) 27-46

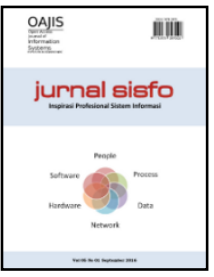

\title{
Pembuatan Standard Operating Procedure Perawatan Sistem Informasi Manajemen Institut Teknologi Sepuluh Nopember
}

\author{
Bekti Cahyo Hidayanto*, Andy Novian Ragiltya, Anisah Herdiyanti \\ Departemen Sistem Informasi, Fakultas Teknologi Informasi, Institut Teknologi Sepuluh Nopember
}

\begin{abstract}
The maintenance process of Information System Management (MIS) is important to ensure that the MIS has been developed and managed correctly. However, Direktorat Pengembangan Sistem Informasi (Subdit PSI) DPTSI ITS Surabaya carries out maintenance activities based on the event of a problem in their MIS. There is lack of standardization on how to perform maintenance activities. Therefore, a Standard Operating Procedures (SOP) document is needed, which is developed based on the gap between the current condition with ideal conditions based on expectations and reference standards, i.e. ISO/IEC 14764:2006, backup and monitoring and control based on ITILv3. The results from this study are documents regarding SOP SIM maintenance, which consists of 6 procedures and 9 forms. The SOP documents shall provide a reference for Subdit PSI DPTSI ITS in carrying out the maintenance process of their MIS.
\end{abstract}

Keywords: Maintenance of MIS, Standard Operating Procedure (SOP), Gap Analysis, ISO/IEC 14764:2006, ITILv3

\begin{abstract}
Abstrak
Proses perawatan terhadap Sistem Informasi Manajemen (SIM) berperan penting untuk memastikan SIM yang telah dikembangkan dan dikelola berjalan sesuai dengan fungsi dan tujuannya. Namun, Sub Direktorat Pengembangan Sistem Informasi (Subdit PSI) DPTSI ITS Surabaya selaku pelaksana tidak melaksanakan aktivitas perawatan secara menyeluruh, dan dilakukan hanya pada saat terjadi permasalahan pada SIM. Oleh karena itu, dibutuhkan sebuah dokumen Standard Operating Procedures (SOP) yang dibuat berdasarkan metode analisis kesenjangan untuk mengukur tingkat kesenjangan antara kondisi kekinian dengan kondisi ideal berdasarkan ekspektasi dan standar acuan yang digunakan dalam penelitian ini, yaitu: ISO/IEC 14764:2006 mengenai perawatan sistem informasi dan ITILv3 yang berkaitan dengan aktivitas monitoring and control dan backup. Hasil luaran berupa dokumen SOP mengenai perawatan SIM, yang terdiri dari 6 prosedur dan 9 formulir. Keseluruhan dokumen SOP nantinya dapat menjadi acuan bagi Subdit PSI DPTSI ITS Surabaya dalam melaksanakan proses perawatan terhadap SIM yang telah dikembangkan.
\end{abstract}

Kata kunci: Perawatan SIM, Standard Operating Procedure (SOP), Analisis Kesenjangan, ISO/IEC 14764:2006, ITILv3

(C) 2017 Jurnal SISFO.

Histori Artikel : Disubmit 18 Januari 2017; Diterima 31 Maret 2017; Tersedia Online 30 September 2017

*Corresponding Author

Email address: bekticahyo@gmail.com (Bekti Cahyo Hidayanto) 


\section{Pendahuluan}

Perawatan (maintenance) adalah salah satu proses penting yang harus dilakukan setelah dilakukan pengembangan sebuah perangkat lunak. Perawatan dilakukan untuk menjaga atau memperbaiki fasilitas yang ada sehingga sesuai dengan standar (baik secara fungsional dan kualitas), sehingga dalam kondisi terbaik dan dapat berjalan sesuai dengan tujuannya [1]. Perawatan sistem juga merupakan tindakan terbaik untuk mencegah terjadinya kesalahan dalam menjalankan sebuah proses. Dalam melaksanakan proses perawatan tersebut, dibutuhkan prosedur yang digunakan sebagai panduan atau acuan bagi pihak-pihak di dalam organisasi tersebut untuk dapat memastikan bahwa proses perawatan yang dijalankan telah sesuai dengan standar atau acuan yang tepat.

Direktorat Pengembangan Teknologi dan Sistem Informasi (DPTSI) ITS Surabaya sebagai lembaga penyelenggaraan layanan utama Teknologi Sistem Informasi (TSI) yang terdapat di lingkup kampus ITS Surabaya membagi peran/fungsi tata kelola pada layanan TSI menjadi tiga kelompok layanan, dimana salah satunya adalah Sub Direktorat Pengembangan Sistem Informasi (Subdit PSI) [2]. Pada kelompok Subdit PSI salah satu tugas pokok yang dikerjakan adalah melakukan perawatan (maintenance) terhadap sistem informasi. Sistem informasi yang dimaksud, salah satunya berupa Sistem Informasi Manajemen (SIM) yang telah dikembangkan oleh DPTSI di lingkup kampus ITS Surabaya [3].

Pada kenyataan yang saat ini terjadi, Subdit PSI tidak memiliki prosedur yang baku sebagai panduan atau acuan dalam melakukan proses perawatan terhadap SIM yang dikelola. Proses perawatan yang saat ini dilakukan, bersifat quick respons dimana proses perawatan terhadap SIM tersebut dilaksanakan apabila pengguna/unit di lingkup kampus ITS Surabaya melaporkan permasalahan yang dihadapi ketika menggunakan SIM kepada Subdit PSI. proses perawatan dilaksanakan hanya berdasarkan permasalahan yang didapatkan dalam proses operasional SIM setiap harinya. Tidak pernah ada aturan yang baku dalam proses perawatan terhadap SIM yang dikelola oleh Subdit PSI. Oleh karena itu, diperlukan prosedur yang terstandar sebagai panduan atau acuan dalam melakukan proses perawatan SIM sesuai dengan standar dan kontrol yang ada, yang didokumentasikan dalam bentuk dokumen SOP, dalam bentuk hard copy (offline) dan soft copy (online).

Berdasarkan studi pendahuluan yang dilakukan oleh penulis, dokumen SOP yang diimplementasikan nantinya menggunakan metode analisis kesenjangan (gap analysis) terhadap kondisi kekinian proses perawatan ketiga SIM dengan kondisi ideal yang disesuaikan dengan standar ISO/IEC 14764:2006 Software Engineering-Software Life Cycle Processes-Maintenance, sebagai kontrol dalam melaksanakan proses perawatan terhadap SIM [1]. Dikarenakan pada standar acuan ISO/IEC 14764:2006 tidak mencakup tentang detail aktivitas backup dan pemantauan yang merupakan salah satu bagian dari aktivitas perawatan, maka ditambahkan kontrol pelengkap dalam proses perawatan yang berupa pemantauan dan kontrol (monitoring and control) aktivitas operasional pada SIM, serta aktivitas backup dari IT Operation Management Function pada level Service Operation di kerangka kerja ITILv3 [4]. Sehingga, diharapkan dokumen SOP Perawatan SIM ini dapat dijadikan sebagai panduan bagi pengelola SIM, dalam hal ini Subdit PSI DPTSI ITS Surabaya dalam melaksanakan proses perawatan SIM yang sesuai dengan standar.

\section{Tinjauan Pustaka/Penelitian Sebelumnya}

\subsection{Sistem Informasi Manajemen (SIM)}

Menurut Turban, McLean, serta Waterbe, didalam buku Information Technology for Management Making Connection for Strategies Advantages [5], Sistem Informasi Manajemen (SIM) adalah suatu sistem yang mengumpulkan (collect), memproses (processing), menyimpan (save), menganalisa (analyze), serta juga menyebarkan (spread) informasi untuk tujuan yang lebih spesifik. 


\subsection{Perawatan Perangkat Lunak}

Perawatan perangkat lunak (software maintenance) menurut ISO/IEC 14764:2006 adalah aktivitas yang dimulai sejak perangkat lunak mulai digunakan (after delivery) hingga akhirnya perangkat lunak tersebut tidak dapat digunakan lagi (retired) [1]. Tujuannya adalah untuk memperbaiki kesalahan (to correct), meningkatkan kinerja/fungsionalitas (to improve), menyesuaikan dengan lingkungan (to adapt), atau untuk mencegah terjadinya kesalahan (to prevent).

\subsection{ISO/IEC 14764:2006}

ISO/IEC 14764:2006 Software Engineering-Software Life Cycle Processes-Maintenance merupakan salah satu kerangka kerja tata kelola TI yang berfungsi agar menjamin bahwa organisasi TI dapat mendukung dan memperluas sasaran serta strategi organisasi [6]. Kerangka kerja ini digunakan dalam melakukan proses perawatan perangkat lunak. ISO/IEC 14764:2006 digunakan untuk memberikan panduan tentang pengelolaan (atau bagaimana melakukan) proses perawatan perangkat lunak, seperti mengidentifikasi bagaimana proses perawatan perangkat lunak dapat dilakukan pada kondisi tertentu [1]. Aktivitas perawatan perangkat lunak, pada standar acuan yang telah digunakan di ISO/IEC 14764:2006, digambarkan pada Gambar.1.

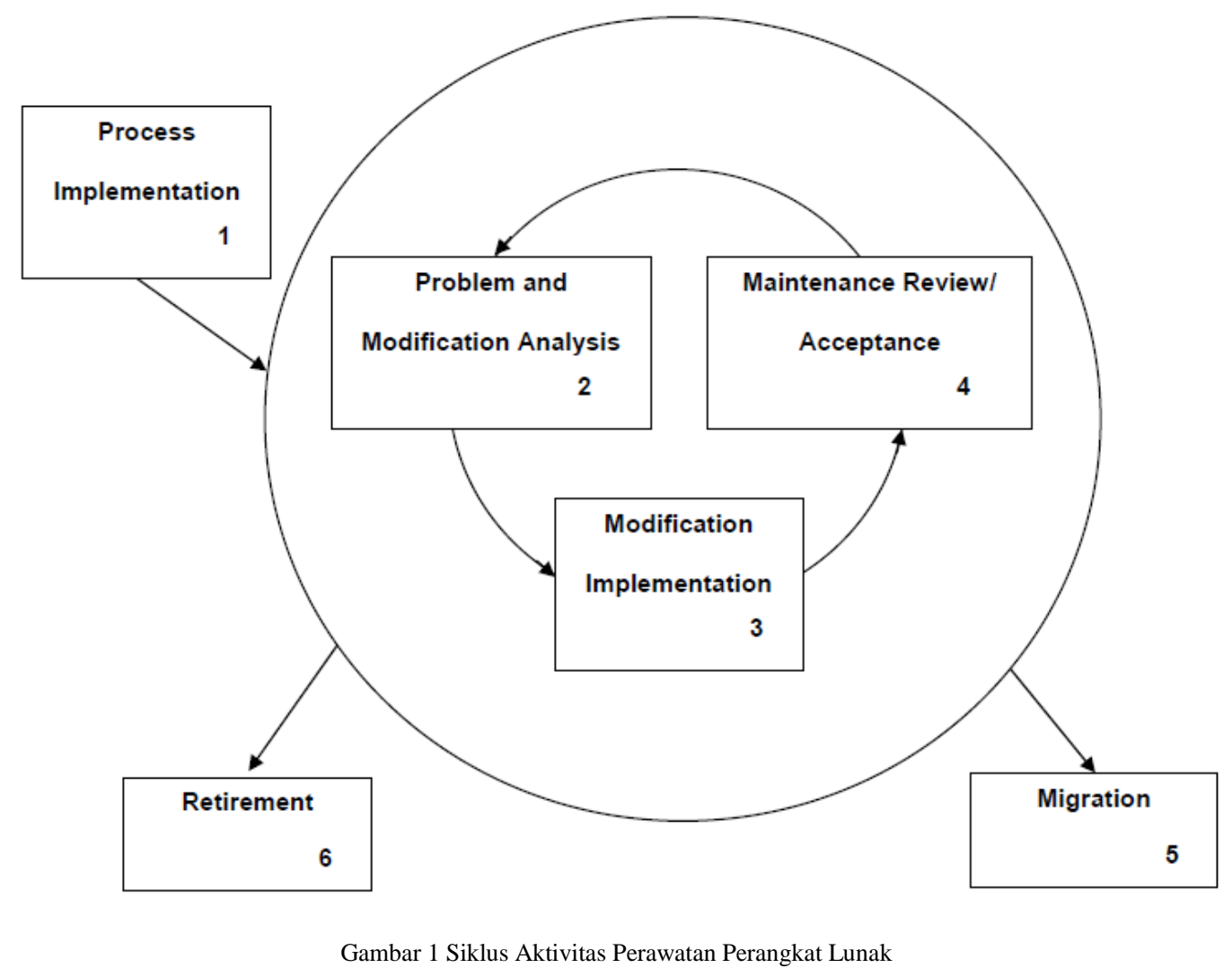

(Sumber: ISO/IEC 14764:2006 Software Engineering-Software Life Cycle Processes-Maintenance, 2006)

ISO/IEC 14764:2006 berisi poin-poin sebuah kontrol yang lebih detil mengenai aktivitas perawatan perangkat lunak. Namun, pada standar acuan ISO/IEC 14764:2006 ini tidak memiliki kontrol terkait aktivitas perawatan lainnya yang dilakukan dalam penyusunan dokumen SOP Perawatan SIM ini, yaitu 
aktivitas backup dan pemantauan SIM. Oleh karena itu dibutuhkan standar acuan kerangka kerja ITILv3 pada bagian IT Operation Management Function level Service Operation yang menjelaskan acuan yang ddapat digunakan dalam melakukan aktivitas perawatan SIM terkait backup dan monitoring and control. Lebih lanjut mengenai standar tersebut dipaparkan pada subbab selanjutnya.

\subsection{IT Operation Management Function - ITILv3}

Best Practices pada bagian IT Operation Management Function level Service Operation di kerangka kerja ITILv3, salah satunya mencakup aktivitas terkait monitoring and control dan juga backup. Pemilihan IT Operation Management Function ini disebabkan karena pada standar acuan ISO/IEC 14764:2006 belum mencakup detail mencakup aktivitas terkait monitoring and control dan juga backup yang juga merupakan tugas pokok perawatan SIM di Subdit PSI DPTSI ITS Surabaya.

Aktivitas yang berkaitan dengan IT Operation berdasarkan ITILv3 mencakup:

\section{1) Monitoring and Control}

a) Mendefinisikan lingkungan dan objek yang akan diuji

b) Mendefinisikan tujuan aktivitas monitoring and control

c) Menentukan tools yang digunakan dalam aktivitas monitoring and control

d) Menentukan tipe monitoring yang dilakukan (Active, Pasive, Proactive atau Reactive Monitoring)

e) Menentukan tipe kontrol pengukuran monitoring yang digunakan (Continuous Measurement atau Exception-Based Measurement)

f) Melakukan monitoring pada lingkungan yang diuji

g) Melakukan monitoring pada objek yang diuji

h) Melakukan tindakan perbaikan terhadap permasalahan yang ditemui

i) Menyusun laporan hasil pemantauan dan tindakan yang akan dilakukan dari hasil pemantauan tersebut

2) Backup
a) Identifikasi data/sistem yang di-backup
b) Identifikasi frekuensi, jarak atau interval dilakukannya backup
c) Menentukan tipe backup yang digunakan (full backup, partial backup, incremental backup)
d) Menentukan lokasi penyimpanan data yang di-backup.
e) Menentukan metode transportasi backup (transfer dengan menggunakan jaringan, transfer menggunakan penyimpanan fisik atau media magnetik).
f) Menentukan Recovery Point Objective (ambang berapa banyak data yang boleh hilang sejak terakhir backup dilakukan).
g) Menentukan Recovery Time Objective (lama waktu pemulihan).
h) Melakukan proses backup dan melakukan
i) pengujian atau pengecekan (verifikasi) terhadap data/sistem yang telah di-backup (untuk menguji apakah data/sistem tersebut dapat dibaca, dapat di-restore dan lain sebagainya).
j) Menyimpan hasil backup dan melakukan pencatatan proses backup

\subsection{Analisis Kesenjangan}

Analisis kesenjangan (gap analysis) merupakan akitivitas membandingkan kondisi aktual dengan kondisi ideal [7]. Hal ini dapat menjadikan evaluasi bisnis yang memfokuskan pada kesenjangan kondisi aktual dengan kondisi ideal. Analisis kesenjangan dapat mengindetifikasi proses-proses yang perlu dilakukan untuk mengurangi kesenjangan agar tercapainya kondisi yang ideal. Kesenjangan ( gap) yang dijadikan acuan dalam penelitian ini adalah GAP 2, mengenai kesenjangan antara persepsi manajemen dan standar kualitas layanan. 


\subsection{Standard Operating Procedure (SOP)}

Standard Operating Procedure, merupakan bentuk dari tata kelola teknologi informasi berupa peraturan tertulis yang membantu dalam mengontrol perilaku organisasi [8]. SOP mempunyai peran penting dalam menjelaskan rincian aktivitas dari proses yang dijalankan, adanya standarisasi aktivitas, dapat membantu dalam pengambilan keputusan, memudahkan dalam transparansi dan akuntabilitas sebuah organisasi serta dapat memberikan arahan kerja berupa konsep yang jelas. SOP dirancang berdasarkan pada peraturan pemerintah (Menteri Pendayagunaan Aparatur Negara dan Reformasi Birokrasi Republik Indonesia Nomor 35 tahun 2012) [8, 9], yang kemudian nantinya dirancang dalam bentuk online menggunakan Office 365.

\subsection{Penelitian Sebelumnya terkait Pembuatan SOP}

Penelitan ini merupakan rangkaian penelitian yang menggunakan DPTSI ITS Surabaya sebagai objek studi. Ataina dalam [10] memfokuskan pada pembuatan SOP untuk manajemen akses SIM sementara Puspitaningrum dalam [11] membahas pembuatan SOP untuk pengembangan SIM di DPTSI ITS. Pembuatan SOP yang mengacu kepada studi sebelumnya yang membahas pembuatan SOP khususnya yang memfokuskan pada kajian mengenai Service Operation di kerangka kerja ITILv3, diantaranya: Rachmi dalam [12] dan Restiana dalam [13]. Penelitian-penelitian tersebut memberikan acuan dalam implementasi kerangka kerja ITIL v3 di unit bisnis melalui pembuatan SOP yang mendukung layanan TI yang dikelola oleh unit bisnis tersebut.

\section{Metodologi}

Pengerjaan penelitian ini melalui beberapa metode yang meliputi tahap persiapan, pengumpulan data, analisis, perancangan dan pembuatan SOP, hingga tahap akhir terkait hasil dan pembahasan. Gambaran alur/metodologi proses pengerjaan penelitian ini terdapat pada Gambar 2.

\subsection{Tahap Persiapan}

Tahap persiapan yang dilakukan dalam penelitian ini adalah melakukan studi literatur dan studi dokumen. Untuk aktivitas studi literatur dan studi dokumen dilakukan sebagai tinjauan pustaka dari peneliti untuk dapat memperkaya pengetahuan terkait aktivitas perawatan SIM di Sub Direktorat Pengembangan Sistem Informasi (Subdit PSI) DPTSI ITS Surabaya, serta cara mengembangkan dokumen SOP yang sesuai dengan standar.

\subsection{Tahap Penggalian Data dan Informasi}

Tahap penggalian data dan informasi yang dilakukan terdiri dari tiga proses, yaitu penyusunan interview protocol yang digunakan dalam proses kedua, wawancara dengan Subdit PSI selaku pelaksana aktivitas perawatan layanan yang selama ini dilakukan di lingkup kampus ITS Surabaya. Setelah data dan informasi terkait aktivitas perawatan telah didapatkan, sebelum melakukan analisisnya, melakukan verifikasi terhadap data dan informasi yang didapatkan dari hasil wawancara kepada narasumber. Dari verifikasi data dan informasi, maka peneliti dapat mengetahui kondisi kekinian aktivitas perawatan SIM di DPTSI ITS Surabaya yang selama ini telah dilakukan. 


\section{Tahap Persiapan}

Melakukan Studi Literatur dan Studi Dokumen

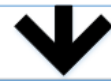

Tahap Penggalian Data dan Informasi

- Penyusunan Interview Protocol

- Melakukan Wawancara dan Observasi Kondisi Kekinian dan Harapan Perawatan SIM di DPTSI

- Verifikasi dan Validasi Hasil Wawancara

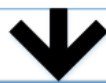

\section{Tahap Analis is}

- Analisis Kondisi Kekinian dan Kondisi Ideal Perawatan SIM

- Analisis Kesenjangan Kondisi Kekinian dan Kondisi Ideal (Berdasarkan Gap 2)

- Menentukan Hasil Analisis Kesenjangan

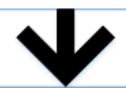

\section{Tahap Perancangan dan Pembuatan SOP}

- Perancangan Struktur dan Konten SOP berdasarkan Peraturan Pemerintah (Offline) dan Office 365 (Online)

- Penyusunan Dokumen SOP Perawatan SIM

- Verifikasi dan Validasi Dokumen SOP Perawatan SIM

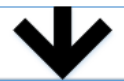

\section{Tahap Akhir}

- Perbaikan dan Penyusunan Dokumen SOP

Perawatan SIM secara Offline dan Online hasil Verifikasi dan Validasi

- Penarikan Kesimpulan dan Saran 


\section{.3.3 Tahap Analisis}

Tahap analisis yang dilakukan adalah menganalisis terhadap kondisi kekinian dan kondisi ideal perawatan SIM sesuai dengan standar acuan ISO/IEC 14764:2006 tentang perawatan perangkat lunak, serta aktivitas backup dan monitoring yang sesuai dengan aktivitas pada IT Operation Management Function ITILv3. Kemudian, diperoleh kesenjangan dari kedua kondisi tersebut. Pada tahap ini diperoleh hasil kesenjangan antara kondisi kekinian dan kondisi ideal perawatan SIM, serta usulan SOP yang dibuat.

\subsection{Tahap Perancangan dan Pembuatan SOP}

Tahap perancangan dan pembuatan SOP yang dilakukan adalah melakukan perancangan terhadap struktur dan konten dari usulan SOP yang akan dibuat. Struktur dan konten dari dokumen SOP disesuaikan dengan kondisi ideal dari standar acuan yang digunakan dan kondisi yang diinginkan oleh Subdit PSI berdasarkan peraturan pemerintah dan pembuatan dokumen versi online menggunakan Office 365. Setelah dokumen SOP dibuat, peneliti melakukan verifikasi dan validasi dokumen SOP yang telah dibuat untuk memastikan bahwa dokumen tersebut dapat dipahami oleh pelaksana aktivitas perawatan SIM dan dan dapat diimplementasikan kedepannya supaya aktivitas perawatan dapat berjalan dengan maksimal

\subsection{Tahap Akhir}

Tahap akhir yang dilakukan adalah melakukan perbaikan pada dokumen SOP berdasarkan dari hasil verifikasi dan validasi, serta menyusun kesimpulan dan saran dari penelitian.

\section{Hasil dan Pembahasan}

\subsection{Hasil Penggalian Data Kondisi Kekinian dan Ekspektasi Proses Perawatan SIM di DPTSI ITS Surabaya}

Berdasarkan perancangan penggalian data yang diperlukan dalam penelitian, dapat dilakukan kegiatan penggalian data seperti wawancara dan observasi secara langsung kepada pihak Subdit PSI DPTSI ITS Surabaya. Wawancara dilakukan enam kali pada tanggal 11 Agustus 2015, 15 September 2015, 21 Oktober 2015, 9 November 2015 dan 20 Juni 2016, dan 22 November 2016. Topik wawancara secara singkat berisi poin sebagai berikut:

1) Penjelasan terkait Tupoksi Subdit PSI DPTSI ITS Surabaya.

2) Penjelasan terkait Sistem Informasi Manajemen (SIM) yang dikelola oleh Subdit PSI DPTSI ITS Surabaya.

3) Penjelasan terkait aktor dan role pada proses perawatan SIM.

4) Penjelasan terkait kondisi kekinian proses perawatan SIM yang dikelola oleh Subdit PSI DPTSI ITS Surabaya.

5) Penjelasan terkait kondisi ekspektasi proses perawatan SIM yang dikelola oleh Subdit PSI DPTSI ITS Surabaya.

6) Penjelasan terkait aktor dan role pada aktivitas pemantauan SIM.

7) Penjelasan terkait kondisi kekinian aktivitas pemantauan SIM yang dikelola oleh Subdit PSI DPTSI ITS Surabaya.

8) Penjelasan terkait kondisi ekspektasi aktivitas pemantauan SIM yang dikelola oleh Subdit PSI DPTSI ITS Surabaya.

9) Penjelasan terkait kondisi ekspektasi proses pemantauan SIM yang dikelola oleh Subdit PSI DPTSI ITS Surabaya.

10) Penjelasan terkait aktor dan role pada aktivitas backup data dan sistem informasi pada SIM.

11) Penjelasan terkait kondisi kekinian aktivitas backup data dan sistem informasi pada SIM yang dikelola oleh Subdit PSI DPTSI ITS Surabaya. 
12) Penjelasan terkait kondisi ekspektasi aktivitas backup data dan sistem informasi pada SIM yang dikelola oleh Subdit PSI DPTSI ITS Surabaya.

13) Penjelasan terkait perubahan struktur organisasi, perubahan sistem dan permintaan penambahan prosedur perawatan SIM yang meliputi migrasi dan retirement.

14) Penjelasan terkait pembuatan formulir untuk dokumen SOP versi online menggunakan Office 365.

Dari hasil penggalian data tersebut didapatkan beberapa fakta atau temuan yang menggambarkan secara umum kondisi kekinian pengembangan SIM yang secara singkat diuraikan dalam poin berikut:

1) Sub Direktorat Pengembangan Sistem Informasi (Subdit PSI) DPTSI ITS Surabaya memiliki jumlah staf yang berjumlah 14 orang.

2) Tupoksi dari Koordinator Subdit PSI DPTSI menjelaskan tentang tugas dari staf yang terkait dengan proses perawatan SIM.

3) Proses perawatan SIM dilakukan untuk unit di dalam lingkup kampus ITS Surabaya.

4) Pembagian jobdesk tidak begitu terperinci sehingga tak ada yang mengetahui lebih detail dan jelas terkait proses perawatan SIM yang dilakukan oleh staf pada SIM tertentu.

5) Selama ini proses perawatan SIM yang dilakukan oleh Subdit PSI DPTSI ITS Surabaya terdiri dari tiga macam proses, yakni 1) proses perawatan SIM ketika terjadi permintaan modifikasi atau perbaikan permasalahan dalam SIM yang ditemukan oleh Admin SIM, pelanggan/unit pengguna SIM, dan pengembang SIM; 2) monitoring and control, untuk melakukan pemantauan kinerja sistem; dan 3) aktivitas backup database dan sistem informasi.

6) Jumlah permintaan proses perawatan SIM, terutama yang bersifat perbaikan (corrective) dari pengguna SIM dalam satu hari bersifat tak menentu, terkadang bisa banyak atau sedikit

7) Proses perawatan SIM yang selama ini dilakukan rata-rata berupa perbaikan SIM yang ditangani secara cepat (quick response).

8) Subdit PSI DPTSI ITS Surabaya harus mampu menangani permasalahan yang terdapat dalam SIM dalam waktu yang cepat sebagai bentuk proses perawatan SIM

9) Permasalahan di dalam SIM sebagai bentuk proses perawatan SIM yang dapat ditangani oleh Pusbang DPTSI ITS Surabaya terkait seputar permasalahan pada data dan error pada source code, query atau modul sistem. Sedangkan permasalahan yang terkait dengan server, jaringan, OS, remote, hardisk, dan lain sebagainya diserahkan pada Subdit Infrastruktur dan Keamanan Teknologi Informasi (IKTI) DPTSI ITS Surabaya yang tetap berkoordinasi dengan Subdit PSI.

10) Subdit PSI DPTSI ITS Surabaya belum memiliki pedoman yang terstandarisasi untuk aktivitas perawatan SIM, sehingga proses perawatan SIM selama ini tidak berjalan sesuai dengan aturan yang ada, dijalankan berdasarkan kebiasaan aktivitas yang selalu dilakukan sehingga tidak terdapat dokumentasi proses perawatan SIM selama ini.

11) Setelah terjadi perubahan dalam struktur organisasi pada DPTSI ITS Surabaya, saat ini terdapat pergantian pada kepala lembaga dan kepala koordinator. Selain itu, adanya penghapusan unit layanan dari 4 menjadi 3 unit layanan.

12) Perubahan sistem, dimana saat ini semua permintaan yang masuk ke dalam DPTSI harus dan wajib melalui sistem umpan balik ITS.

13) Perlu adanya penambahan pembuatan prosedur dalam menjalankan aktivitas migrasi dan retirement, untuk disesuaikan dengan standar ISO yang digunakan.

14) Perlu adanya pendokumentasian aktivitas perawatan SIM secara online dengan menggunakan aplikasi form di Office 365 .

Setelah mendapatkan data dan informasi yang dibutuhkan, selanjutnya penulis melakukan analisis kondisi kekinian dengan kondisi ekspektasi yang diharapkan oleh Subdit PSI DPTSI ITS Surabaya maupun kondisi ideal berdasarkan standar acuan yang digunakan. 


\subsection{Analisis Kondisi Kekinian dan Kondisi Ideal Proses Perawatan SIM}

Pada bagian ini, peneliti melakukan analisis kondisi kekinian dengan kondisi ekspektasi yang diharapkan oleh Subdit PSI DPTSI ITS Surabaya maupun kondisi ideal berdasarkan standar acuan. Dalam melakukan analisis, penulis mengacu pada 4 aspek penting dalam mendesain sebuah layanan TI berdasarkan tahapan service design ITIL V3, yaitu People, Processes, Product dan Partners [10]. Dalam penelitian, peneliti menggunakan aspek people dan processes, karena dua aspek tersebut merupakan unsur penting yang harus terdapat di dalam proses perawatan SIM. Sedangkan terkait kondisi ideal proses perawatan SIM, peneliti menggunakan standar acuan ISO/IEC 14764:2006 dan IT Operation Management Function di kerangka kerja ITILv3 pada aktivitas backup dan monitoring and control. Tabel 1 merangkum kondisi kekinian dan kondisi ekspektasi maupun kondisi ideal berdasarkan aspek yang digunakan,

Tabel 1 Analisis Kondisi Kekinian dan Kondisi Ideal

\begin{tabular}{|c|c|c|}
\hline Aspek & Sub Aspek & $\begin{array}{c}\text { Analisis Kondisi Kekinian } \\
\text { (as is) }\end{array}$ \\
\hline \multirow{3}{*}{ People } & $\begin{array}{l}\text { Ketersediaan } \\
\text { SDM }\end{array}$ & $\begin{array}{l}\text { Sub Direktorat Pengembangan Sistem Informasi } \\
\text { (Subdit PSI) saat ini memiliki jumlah staf yang } \\
\text { berjumlah } 14 \text { orang yang dibina oleh DPTSI ITS } \\
\text { Surabaya dan dipekerjakan untuk membantu } \\
\text { Subdit PSI dalam proses pengembangan dan } \\
\text { perawatan SIM. }\end{array}$ \\
\hline & Jobdesk SDM & $\begin{array}{l}\text { Detail penjelasan jobdesk dari masing-masing } \\
\text { staf kurang dijelaskan sehingga setiap staf dapat } \\
\text { melakukan tugas yang sama. Selama ini juga } \\
\text { pelaksanaan proses perawatan SIM yang selama } \\
\text { ini berbentuk perbaikan terhadap permasalahan } \\
\text { (corrective maintenance), hanya dilaporkan dari } \\
\text { pelanggan/unit SIM kepada beberapa orang } \\
\text { tertentu, yang juga melaksanakan aktivitas lain } \\
\text { selain proses perawatan, sehingga terkadang } \\
\text { kewalahan dalam menanggapi pemintaan layanan } \\
\text { pelanggan. }\end{array}$ \\
\hline & $\begin{array}{l}\text { Pengetahuan } \\
\text { dan } \\
\text { Kemampuan } \\
\text { SDM }\end{array}$ & $\begin{array}{l}\text { Dari hasil wawancara diketahui bahwa hanya } \\
\text { beberapa staf dari total jumlah tenaga kerja yang } \\
\text { dapat melakukan perawatan SIM secara berkala } \\
\text { dan dengan cepat mampu mengatasi } \\
\text { permasalahan/permintaan modifikasi pada SIM. } \\
\text { Selain itu, kurangnya pelatihan (training) } \\
\text { ataupun sosialisasi dalam melakukan proses } \\
\text { perawatan SIM, yang disebabkan pula karena tak } \\
\text { ada aturan/prosedur yang jelas dalam proses } \\
\text { perawatan SIM selama ini. }\end{array}$ \\
\hline
\end{tabular}

\section{Aktivitas Perawatan SIM:}

\section{- Process Implementation}

Setelah SIM diterapkan/ diimplementasikan, terkadang baik dari pengguna/unit mengalami kendala/permasalahan, atau ingin melakukan permintaan perubahan pada sistem. Pada awalnya, Pengguna/Unit kemudian mengajukan permintaan modifikasi/pelaporan permasalahan terkait SIM dengan format apapun, atau secara langsung menelepon kepala/staf Subdit PSI. Kepala/staf Subdit PSI menerima laporan/permintaan dan melakukan pencatatan pada kertas atau notes di komputer, dan biasanya untuk kepala subdit akan didelegasikan ke staf
Analisis Kondisi Ideal (to be)

Dalam melakukan suatu perubahan akan lebih efektif apabila dikerjakan oleh SDM dalam jumlah yang sedikit. Begitu juga terkait dengan kondisi ekspektasi dari Subdit PSI DPTSI ITS Surabaya terhadap jumlah SDM yang sudah dianggap cukup tepat.

Dibutuhkan pendefinisian jobdesk yang jelas untuk setiap SDM yang terkait, seperti maintainer (orang yang melakukan koordinasi terhadap proses perawatan, ISO/IEC 14764:2006), dan dokumentator proses. Begitu juga terkait dengan kondisi ekspektasi dari Subdit PSI DPTSI ITS Surabaya, agar jobdesk dapat didefinisikan dengan jelas, sehingga semua permasalahan/permintaan yang dilaporkan oleh pengguna/unit tidak hanya menumpuk pada 1-2 orang tertentu.

SDM yang ada dalam sebuah organisasi TI harus memiliki kemampuan, pengetahuan dalam memanajemen layanan TI dengan baik termasuk dalam melakukan proses perawatan. Hal ini juga sesuai dengan kondisi ekspektasi dari Subdit PSI DPTSI ITS Surabaya, untuk mengadakan sosialisasi SOP sebelum dilaksanakan sehingga pengetahuan dan kemampuan SDM menjadi lebih baik.

\section{Aktivitas Perawatan SIM (berdasarkan ISO/IEC 14764:2006 dan kondisi ekspektasi):}

\section{- Process Implementation}

Seluruh permintaan perbaikan/perawatan SIM dilaporkan melalui Service Desk menggunakan e-tiket di Sistem Informasi Umpan Balik ITS, yang kemudian diidentifikasikan oleh Subdit Layanan TSI supaya dapat mendelegasikan permintaan kepada unit terkait, sehingga tidak semua permintaan atau permasalahan langsung dilaporkan kepada Subdit PSI. Adapun jika pengguna/unit melaporkan langsung ke kepala/staf Subdit PSI, kepala/staf tetap harus melaporkan kepada Service Desk agar tetap tercatat dalam e-tiket. Setelah dipastikan bahwa 


\begin{tabular}{|c|c|c|c|}
\hline Aspek & Sub Aspek & $\begin{array}{c}\text { Analisis Kondisi Kekinian } \\
\text { (as is) }\end{array}$ & $\begin{array}{c}\text { Analisis Kondisi Ideal } \\
\text { (to be })\end{array}$ \\
\hline & & $\begin{array}{l}\text { yang ditunjuk sebagai PIC melakukan analisis } \\
\text { terhadap laporan/permintaan. Sedangkan untuk } \\
\text { staf biasanya langsung melakukan aktivitas } \\
\text { perbaikan/perawatan. Saat ini semua aktivitas } \\
\text { permintaan diharuskan untuk disampaikan } \\
\text { kepada Service Desk menggunakan Sistem } \\
\text { Informasi Umpan Balik ITS } \\
\text { (https://umpanbalik.its.ac.id) dimana setiap } \\
\text { pengguna/unit melaporkan dengan membuka e- } \\
\text { tiket. }\end{array}$ & $\begin{array}{l}\text { permasalahan/permintaan yang diperoleh terkai } \\
\text { dengan bidang kerja Subdit PSI, Service Desk } \\
\text { melaporkan ke Kasubdit PSI yang kemudian } \\
\text { menunjuk PIC untuk melakukan proses } \\
\text { perawatan. Semua proses melalui prosedur } \\
\text { tertulis yang jelas dan sesuai dengan standar da } \\
\text { didokumentasikan. }\end{array}$ \\
\hline & & - Problem and Modification Analysis & - Problem and Modification Analysis \\
\hline & & $\begin{array}{l}\text { Staf Subdit PSI sebagai PIC melakukan } \\
\text { peninjauan terhadap laporan } \\
\text { permasalahan/permintaan modifikasi yang } \\
\text { diterima, kemudian melakukan analisis secara } \\
\text { singkat mengenai permasalahan yang dihadapi } \\
\text { dari permintaan. }\end{array}$ & $\begin{array}{l}\text { PIC melakukan analisis terhadap permasalahan } \\
\text { yang didapatkan, yang diharapkan secara detail } \\
\text { seperti menentukan jenis, ruang lingkup dan } \\
\text { dampak dari permintaan perbaikan/modifikasi } \\
\text { yang didapatkan, hingga mulai melakukan } \\
\text { proses perbaikan/perawatan. Semua proses } \\
\text { melalui prosedur tertulis yang jelas dan sesuai } \\
\text { dengan standar dan didokumentasikan. }\end{array}$ \\
\hline
\end{tabular}

\section{- Modification Implementation}

Proses perawatan dilakukan oleh PIC yang telah ditunjuk untuk melakukan proses, baik itu admin SIM ataupun staf Subdit PSI. Kemudian dilakukan pengecekan dan pemantauan singkat untuk memastikan proses perbaikan/perawatan yang telah dilakukan telah berhasil.

\section{- Maintenance Review/Acceptance}

Hasil dari proses perbaikan/ perawatan selanjutnya diberitahukan kepada pengguna/unit secara langsung melalui konfirmasi melalui email atau telepon, dan jika permintaan berasal dari input pada Sistem Informasi Umpan Balik, maka PIC melakukan penutupan e-tiket.

\section{Migration}

Saat ini belum ada aktivitas/proses migrasi SIM (dalam lingkup skala yang besar) yang dilakukan oleh Subdit PSI DPTSI ITS Surabaya.

\section{Retirement}

Saat ini belum ada aktivitas/proses pemberhentian SIM yang dilakukan oleh Subdit PSI DPTSI ITS Surabaya.

\section{Backup}

\section{- Modification Implementation}

PIC yang melakukan perbaikan mempersiapkan kebutuhan yang diperlukan untuk menyelesaikan permintaan perawatan/ penanganan permasalahan pada SIM, selanjutnya dilakukan perbaikan/perawatan. Perbaikan/perawatan yang sudah selesai kemudian diujicobakan kembali apakah telah sesuai atau tidak berdasarkan teknik pengujian yang dipilih. Setelah proses perbaikan selesai, PIC melaporkan hasil perbaikan kepada user untuk dilakukan peninjauan. Semua proses melalui prosedur tertulis yang jelas dan sesuai dengan standar dan didokumentasikan.

\section{- Maintenance Review/Acceptance}

User dan PIC melakukan peninjauan terhadap hasil perbaikan. Selanjutnya PIC melaporkan kepada Service Desk terkait hasil aktivitas perbaikan/perawatan yang telah dilakukan untuk mengakhiri proses permintaan. Semua proses melalui prosedur tertulis yang jelas dan sesuai dengan standar dan didokumentasikan.

\section{Migration}

Adanya prosedur migrasi SIM. Semua proses melalui prosedur tertulis yang jelas dan sesuai dengan standar dan didokumentasikan.

\section{Retirement}

Adanya prosedur pemberhentian SIM. Semua proses melalui prosedur tertulis yang jelas dan sesuai dengan standar dan didokumentasikan.

\section{Backup}




\begin{tabular}{|c|c|c|c|}
\hline Aspek & Sub Aspek & $\begin{array}{c}\text { Analisis Kondisi Kekinian } \\
\text { (as is) }\end{array}$ & $\begin{array}{c}\text { Analisis Kondisi Ideal } \\
\text { (to be })\end{array}$ \\
\hline & & $\begin{array}{l}\text { Alur aktivitas backup yang telah dilakukan } \\
\text { beberapa diantaranya memenuhi standar acuan } \\
\text { yang dilakukan, mulai dari mempersiapkan } \\
\text { kebutuhan, melakukan aktivitas backup dan } \\
\text { melakukan aktivitas restore sebagai pengujian } \\
\text { apakah proses backup berhasil dilakukan atau } \\
\text { tidak. Dokumentasi pencatatan dan penyimpan } \\
\text { hasil backup juga telah dilakukan. }\end{array}$ & $\begin{array}{l}\text { Kasubdit menentukan PIC dan SIM yang akan } \\
\text { di-backup. PIC mempersiapkan kebutuhan } \\
\text { Backup, mengakses server SIM yang akan } \\
\text { dilakukan backup melakukan proses backup } \\
\text { hingga berhasil, dan mengisi formulir laporan } \\
\text { backup secara online yang sesuai dengan } \\
\text { aturan/standar acuan aktivitas backup. Semua } \\
\text { proses melalui prosedur tertulis yang jelas dan } \\
\text { sesuai dengan standar dan didokumentasikan. }\end{array}$ \\
\hline & & Monitoring and Control & Monitoring and Control \\
\hline & & $\begin{array}{l}\text { Aktivitas monitoring and control yang dilakukan } \\
\text { hanya saat terjadi permasalahan dalam SIM yang } \\
\text { dilaporkan oleh pengguna/unit, sehingga } \\
\text { dilakukan secara sekaligus dengan proses } \\
\text { perawatan SIM. Untuk proses pemantauan SIM } \\
\text { secara berkala/terjadwal tidak pernah dilakukan. }\end{array}$ & $\begin{array}{l}\text { Sedangkan untuk kondisi yang diharapkan, } \\
\text { Kasubdit menentukan SIM dan PIC yang akan } \\
\text { melakukan proses pemantauan. PIC } \\
\text { mempersiapkan kebutuhan dalam melakukan } \\
\text { proses pemantauan. PIC kemudian masuk } \\
\text { (login) ke dalam SIM dan melakukan proses } \\
\text { pengecekan fitur, modul dan sebagainya. Ketika } \\
\text { ditemukan permasalahan, maka ditentukan } \\
\text { terlebih dahulu apakah harus ada pihak lain } \\
\text { yang melakukan proses perbaikan atau dapat } \\
\text { ditangani langsung. Setelah selesai, PIC keluar } \\
\text { (logout) dari SIM dan mengisi formulir laporan } \\
\text { pemantauan sebagai dokumentasi secara online. } \\
\text { Semua proses melalui prosedur tertulis yang } \\
\text { jelas dan sesuai dengan standar dan } \\
\text { didokumentasikan. }\end{array}$ \\
\hline & Dokumentasi & $\begin{array}{l}\text { Subdit PSI DPTSI ITS Surabaya belum } \\
\text { melakukan dokumentasi dengan baik. Hal ini } \\
\text { dapat diketahui dari hasil wawancara dengan } \\
\text { pihak terkait, bahwa dokumentasi dan pencatatan } \\
\text { yang dilakukan selama ini tidak tersusun dengan } \\
\text { rapi dan tidak dilakukan secara rutin. Bahkan, } \\
\text { dapat dikatakan segala bentuk alur aktivitas } \\
\text { perawatan SIM yang telah dilakukan selama ini } \\
\text { tidak memiliki dokumentasi tertulis yang tercatat } \\
\text { dengan baik, hanya bersifat note (catatan) saja } \\
\text { yang tidak didokumentasikan, atau dibukukan. } \\
\text { Untuk aktivitas Monitoring and Control dan } \\
\text { Backup sendiri hanya memiliki dokumen } \\
\text { pencatatan akhir pelaksanaan. } \\
\text { Secara keseluruhan, Subdit PSI belum memiliki } \\
\text { panduan dan prosedur yang detail dan jelas } \\
\text { dalam melakukan aktivitas perawatan. }\end{array}$ & $\begin{array}{l}\text { Dari berbagai aktivitas yang ada, proses } \\
\text { dokumentasi harus dilakukan supaya semua } \\
\text { aktivitas yang dilakukan dapat } \\
\text { terdokumentasikan secara terstruktur, dan } \\
\text { mudah dipahami. Dokumentasi dibuat } \\
\text { menggunakan tools seperti formulir yang } \\
\text { digunakan dalam mencatat setiap } \\
\text { aktivitas/proses yang dilakukan di dalam } \\
\text { prosedur melalui online, sehingga prosedur } \\
\text { dapat terdokumentasikan dengan baik }\end{array}$ \\
\hline
\end{tabular}

Setelah melakukan analisis kondisi kekinian dan kondisi ekspektasi maupun kondisi ideal, peneliti melakukan analisis kesenjangan.

\subsection{Analisis Kesenjangan Proses Perawatan SIM}

Analisis kesenjangan dilakukan dengan memastikan kondisi kekinian pada aktivitas perawatan SIM dengan kondisi ideal berdasarkan ekspektasi dari Subdit PSI dan standar acuan yang digunakan. Tabel berikut ini menjelaskan hasil analisis kesenjangan yang telah dilakukan. 
Tabel 2 Analisis Kesenjangan Proses Perawatan SIM

\begin{tabular}{|c|c|c|}
\hline Aspek & Sub Aspek & $\begin{array}{c}\text { Kekurangan Kondisi Kekinian Yang Belum Memenuhi Kondisi } \\
\text { Ideal }\end{array}$ \\
\hline \multirow{4}{*}{ People } & Ketersediaan SDM & - \\
\hline & Jobdesk SDM & $\begin{array}{l}\text { Detail penjelasan jobdesk dari masing-masing staf kurang dijelaskan } \\
\text { sehingga setiap staf dapat melakukan tugas yang sama. Selama ini } \\
\text { juga pelaksanaan proses perawatan SIM yang selama ini berbentuk } \\
\text { perbaikan terhadap permasalahan (corrective maintenance), hanya } \\
\text { dilaporkan dari pelanggan/unit SIM kepada beberapa orang tertentu, } \\
\text { yang juga melaksanakan aktivitas lain selain proses perawatan, } \\
\text { sehingga terkadang kewalahan dalam menanggapi pemintaan }\end{array}$ \\
\hline & & layanan pelanggan. \\
\hline & $\begin{array}{l}\text { Pengetahuan dan } \\
\text { kemampuan SDM }\end{array}$ & $\begin{array}{l}\text { Hanya beberapa staf dari total jumlah tenaga kerja yang dapat } \\
\text { melakukan perawatan SIM secara berkala dan dengan cepat mampu } \\
\text { mengatasi permasalahan/permintaan modifikasi pada SIM. Selain } \\
\text { itu, kurangnya pelatihan (training) ataupun sosialisasi dalam } \\
\text { melakukan proses perawatan SIM, yang disebabkan pula karena tak } \\
\text { ada aturan/prosedur yang jelas dalam proses perawatan SIM selama } \\
\text { ini. }\end{array}$ \\
\hline \multirow[t]{2}{*}{ Processes } & Aktivitas & $\begin{array}{l}\text { Aktivitas perawatan SIM yang dilakukan oleh Subdit PSI selama ini } \\
\text { hanya difokuskan terkait dengan aktivitas perbaikan terhadap } \\
\text { permasalahan pada SIM, belum mencakup semua aktivitas yang ada } \\
\text { pada standar, seperti migrasi dan pemberhentian SIM. Tidak ada } \\
\text { prosedur yang jelas dalam proses perawatan SIM, backup dan } \\
\text { pemantauan SIM. }\end{array}$ \\
\hline & Dokumentasi & $\begin{array}{l}\text { Dokumentasi belum dilakukan dengan baik, disebabkan tidak adanya } \\
\text { prosedur dan formulir yang dapat digunakan untuk mencatat } \\
\text { aktivitas perawatan SIM yang dilakukan. }\end{array}$ \\
\hline
\end{tabular}

Dari hasil analisis kesenjangan yang telah didapatkan, maka selanjutnya dilakukan identifikasi perubahan yang diperlukan untuk menyesuaikan kondisi kekinian menjadi kondisi ideal yang diharapkan oleh Subdit PSI DPTSI. Dengan adanya perubahan maka akan muncul dampak dari perubahannya. Berikut adalah penjelasan detail mengenai perubahan dan dampak yang dihasilkan dari analisis kesenjangan yang dilakukan yang ditunjukkan pada Tabel 3.

Tabel 3 Identifikasi Perubahan dan Dampak

\begin{tabular}{|c|c|c|c|}
\hline Aspek & Sub Aspek & Perubahan & Dampak \\
\hline & Ketersediaan SDM & - & - \\
\hline \multirow[t]{2}{*}{ People } & Jobdesk SDM & $\begin{array}{l}\text { - Kejelasan peran dan fungsi untuk } \\
\text { masing-masing SDM. }\end{array}$ & $\begin{array}{l}\text { - Adanya perubahan restrukturisasi } \\
\text { organisasi. } \\
\text { - Mempercepat kinerja SDM dalam } \\
\text { melakukan proses perawatan SIM. }\end{array}$ \\
\hline & $\begin{array}{l}\text { Pengetahuan dan } \\
\text { kemampuan SDM }\end{array}$ & $\begin{array}{l}\text { - Peningkatan pemahaman SDM terkait } \\
\text { proses perawatan SIM }\end{array}$ & $\begin{array}{l}\text { - Mempercepat kinerja SDM dalam } \\
\text { melakukan proses perawatan. }\end{array}$ \\
\hline Processes & Aktivitas & $\begin{array}{l}\text { Prosedur tertulis yang menjabarkan } \\
\text { setiap aktivitas dalam proses } \\
\text { perawatan SIM. } \\
\text { Penekanan terhadap alur permintaan } \\
\text { layanan yang harus dilaporkan } \\
\text { melalui Service Desk menggunakan } \\
\text { e-tiket Sistem Informasi Umpan } \\
\text { Balik sebagai penerima permintaan } \\
\text { perbaikan/ perawatan SIM dari }\end{array}$ & $\begin{array}{l}\text { - Alur proses Perawatan SIM semakin } \\
\text { teratur dan jelas pelaksanaannya } \\
\text { - Permintaan perawatan SIM lebih } \\
\text { jelas dan terarah sesuai dengan } \\
\text { aturan dari DPTSI dan terstandar. } \\
\text { - Proses Perawatan SIM terkait } \\
\text { Migration dan Retirement dapat } \\
\text { dijalankan sesuai dengan standar dan } \\
\text { semakin lengkap/detail. }\end{array}$ \\
\hline
\end{tabular}




\begin{tabular}{|c|c|c|c|}
\hline Aspek & Sub Aspek & Perubahan & Dampak \\
\hline & & 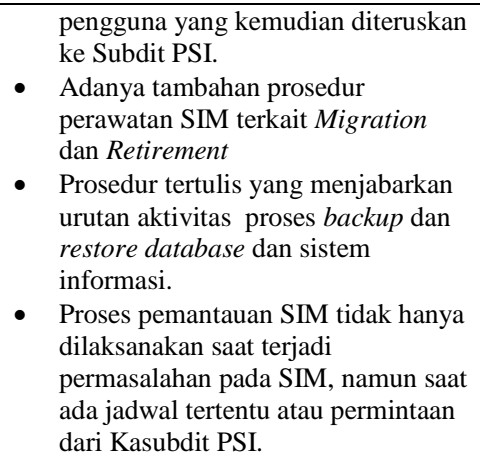 & $\begin{array}{l}\text { - Alur aktivitas backup database dan } \\
\text { sistem informasi semakin teratur dan } \\
\text { jelas pelaksanaannya } \\
\text { - Memiliki pedoman dalam } \\
\text { melaksanakan aktivitas monitoring } \\
\text { and control } \\
\text { - Adanya aktivitas pemantauan SIM } \\
\text { secara berkala dapat mengurangi } \\
\text { permasalahan terhadap SIM }\end{array}$ \\
\hline & Dokumentasi & $\begin{array}{l}\text { Adanya dokumentasi aktivitas perawatan } \\
\text { SIM, termasuk proses backup database } \\
\text { dan sistem informasi, termasuk proses } \\
\text { pemantauan (monitoring and control) } \\
\text { SIM. }\end{array}$ & $\begin{array}{l}\text { Terdapat proses dokumentasi dalam } \\
\text { setiap proses perawatan SIM yang dapat } \\
\text { digunakan sebagai dokumen tetap, } \\
\text { bahan pembelajaran dan evaluasi terkait } \\
\text { aktivitas perawatan SIM. }\end{array}$ \\
\hline
\end{tabular}

Dari penjelasan mengenai perubahan dan dampak yang telah dilakukan, maka dapat juga diidentifikasikan solusi, yang ditunjukkan pada Tabel 4.

Tabel 4 Identifikasi Solusi

\begin{tabular}{|c|c|c|}
\hline Aspek & Sub Aspek & Solusi \\
\hline \multirow[t]{3}{*}{ People } & Ketersediaan SDM & - \\
\hline & Jobdesk & $\begin{array}{l}\text { Perlu adanya mendefinisikan jobdesk (peran dan fungsi) untuk setiap SDM secara jelas, } \\
\text { terstruktur dan terdokumentasi. }\end{array}$ \\
\hline & $\begin{array}{l}\text { Pengetahuan dan } \\
\text { Kemampuan SDM }\end{array}$ & $\begin{array}{l}\text { Perlu adanya sosialiasi terhadap tahapan dalam melakukan proses perawatan SIM, ketika } \\
\text { adanya prosedur yang jelas. }\end{array}$ \\
\hline \multirow[t]{2}{*}{ Processes } & Aktivitas & $\begin{array}{l}\text { - Membuat prosedur tertulis yang menjabarkan aktivitas perawatan yang disesuaikan } \\
\text { dengan kebutuhan organisasi dan standar acuan best practice ISO/IEC 14764:2006, } \\
\text { termasuk penambahan aktivitas Migration dan Retirement. } \\
\text { - Membuat prosedur tertulis yang menjabarkan urutan aktivitas backup dan } \\
\text { monitoring and control yang memenuhi standar acuan aktivitas di kerangka kerja } \\
\text { ITILv3. }\end{array}$ \\
\hline & Dokumentasi & $\begin{array}{l}\text { - Mendokumentasikan segala aktivitas permintaan perawatan, pelaksananaan } \\
\text { perbaikan/ perawatan, migrasi dan pemberhentian SIM, serta aktivitas backup, } \\
\text { monitoring and control dengan baik. } \\
\text { - Pembuatan formulir secara digunakan untuk melakukan perekeman keseluruhan } \\
\text { aktivitas dan hasil dari perawatan SIM yang telah dilakukan. }\end{array}$ \\
\hline
\end{tabular}

Dari hasil identifikasi solusi yang telah dilakukan, selanjutnya digunakan dalam perancangan dan penyusunan dokumen SOP Perawatan SIM.

\subsection{Perancangan dan Penyusunan Dokumen SOP Perawatan SIM}

Dari hasil identifikasi perubahan, dampak dan solusi dari analisis kesenjangan terhadap kondisi kekinian proses perawatan SIM dan kondisi ekspektasi serta kondisi ideal berdasarkan standar acuan, maka diusulkan beberapa SOP yang disusun terkait dengan aktivitas perawatan SIM, seperti yang dijelaskan pada Tabel 5. 
Tabel 5 Usulan SOP

Usulan SOP

Penjelasan

Prosedur permintaan perawatan SIM ini dibuat dengan tujuan sebagai acuan/panduan dalam melakukan proses perawatan SIM pada tahapan awal, yakni melakukan proses permintaan perawatan SIM oleh pengguna SIM (baik pelanggan individu/unit) hingga

Permintaan Perawatan SIM pencatatan penerimaan permintaan sebelum dilakukan aktivtas perbaikan/perawatan pada SIM. Prosedur ini dibuat dan disesuaikan menurut kontrol standar acuan ISO/IEC 14764:2006 pada tahapan aktivitas Process Implementation.

Prosedur perbaikan SIM ini dibuat dengan tujuan sebagai acuan/panduan dalam melakukan pengerjaan aktivitas perbaikan/perawatan SIM berdasarkan kebutuhan dari internal Subdit PSI atau permintaan perawatan SIM yang dilaporkan oleh Service

Perbaikan SIM Desk. Prosedur ini dibuat dan disesuaikan menurut kontrol standar acuan ISO/IEC 14764:2006 pada tahapan aktivitas Problem and Modification Analysis, Modification Implementation hingga aktivitas Maintenance Accept/Review.

Prosedur migrasi SIM ini dibuat dengan tujuan sebagai acuan/panduan dalam melakukan migrasi SIM. Prosedur ini dibuat dan disesuaikan menurut kontrol standar acuan ISO/IEC 14764:2006 pada tahapan aktivitas Migration.

Prosedur pemberhentian SIM ini dibuat dengan tujuan sebagai acuan/panduan dalam

Pemberhentian SIM melakukan pemberhentian SIM. Prosedur ini dibuat dan disesuaikan menurut kontrol standar acuan ISO/IEC 14764:2006 pada tahapan aktivitas Retirement.

Prosedur backup database dan sistem informasi ini dibuat sebagai acuan/panduan dalam melakukan aktivitas backup database dan sistem informasi yang dimiliki oleh

Backup Database dan Sistem Informasi SIM. Prosedur ini dibuat dan disesuaikan menurut kontrol standar acuan kerangka kerja ITILv3 yang terkait dengan aktivitas Backup pada IT Operation Management Function di level Service Operation.

Prosedur pemantauan SIM ini berisi panduan yang dapat digunakan sebagai acuan/panduan dalam melakukan pemantauan SIM. Prosedur ini dibuat dan disesuaikan menurut kontrol standar acuan kerangka kerja ITILv3 yang terkait dengan aktivitas Monitoring and Control pada IT Operation Management Function di level

Pemantauan SIM Service Operation.

Dari usulan prosedur tersebut, peneliti menyusun dokumen Standard Operating Procedure (SOP) Perawatan SIM. Penyusunan dokumen SOP mengacu pada Peraturan Menteri Pendayagunaan Aparatur Negara dan Reformasi Birokrasi Republik Indonesia Nomor 35 Tahun 2012 Tentang Pedoman Penyusunan Standar Operasional Prosedur Administrasi Pemerintahan. Penulis kemudian melakukan penyusunan struktur dan konten SOP sehingga dihasilkan beberapa formulir seperti yang dijelaskan pada Tabel 6.

Tabel 6 Formulir SOP

\begin{tabular}{cccc}
\hline \multicolumn{1}{c}{ No SOP } & Nama SOP & No Formulir & Nama Formulir \\
\hline SOP-SubditPSI-001 & $\begin{array}{c}\text { SOP Permintaan } \\
\text { Perawatan SIM }\end{array}$ & FRM- SubditPSI-001 & $\begin{array}{l}\text { Formulir Permintaan Perawatan } \\
\text { SIM }\end{array}$ \\
SOP- SubditPSI-002 & SOP Perbaikan SIM & FRM- SubditPSI-002 & Formulir Pengujian dan Evaluasi \\
& FRM- SubditPSI-003 & Formulir Laporan Perbaikan SIM \\
SOP-SubditPSI-003 & FRM- SubditPSI-004 & Formulir Berita Acara Diskusi \\
& & FRM- SubditPSI-005 & Formulir Spesifikasi Kebutuhan
\end{tabular}




\begin{tabular}{cccc}
\hline No SOP & Nama SOP & No Formulir & Nama Formulir \\
& & FRM- SubditPSI-006 & Formulir Laporan Migrasi SIM \\
SOP-SubditPSI-004 & SOP Pember hentian & FRM-SubditPSI-007 & $\begin{array}{l}\text { Formulir Laporan Pemberhentian } \\
\text { SIM }\end{array}$ \\
SOP- SubditPSI-005 & SOP Backup & FRM- SubditPSI-008 & $\begin{array}{l}\text { Formulir Laporan Backup Database } \\
\text { dan Sistem Informasi }\end{array}$ \\
& $\begin{array}{c}\text { Satabase dan } \\
\text { Sistem Informasi }\end{array}$ & & \\
SOP-SubditPSI-006 & FRM- SubditPSI-009 & Formulir Laporan Pemantauan \\
& SIM & & \\
\hline
\end{tabular}

Berikut ini adalah contoh dari alur prosedur dan formulir yang ada pada dokumen SOP Perawatan SIM yang telah dihasilkan, pada SOP Permintaan Perawatan SIM. Sesuai dengan standar penyusunan dokumen SOP, terdapat dua unsur utama dalam dokumen, yaitu terkait Deskripsi dan Informasi SOP yang ditunjukkan pada Gambar 3, dan alur prosedur yang ditunjukkan pada Gambar 4.

\begin{tabular}{|c|c|c|}
\hline \multicolumn{3}{|c|}{ PERMINTAAN PERAWATAN SISTEM INFORMASI MANANEMEN } \\
\hline \multirow{6}{*}{$\begin{array}{l}\text { INSTITUT TEKNOLOGI } \\
\text { SEPULUH NOPEMBER } \\
\text { DIREKTORAT PENGEMBANGAN } \\
\text { TEKNOLOGI DAN SISTEM INFORMASI }\end{array}$} & Nomor SOP & 5OP-SubditPSI-001 \\
\hline & Nama 50P & SOP Permintaan Perawatan SIM \\
\hline & Tanggal Pembuatan & $20 / 12 / 2016$ \\
\hline & Tanggal Revisi & $30 / 12 / 2016$ \\
\hline & Tanggal Berlaku & $03 / 01 / 2017$ \\
\hline & Disahkan Oleh & $\frac{\text { (Anmy Yuniarti, S.Kom., M.Comp.SC.) }}{\text { Kepala Subdit PSI DPTSI ITS Surabaya }}$ \\
\hline DESKRIPSI SOP & \multicolumn{2}{|c|}{ KUAUFIKASI DAN DAFTAR PELAKSANA } \\
\hline $\begin{array}{l}\text { SOP Permintaan Perawatan SIM } \\
\text { merupakan panduan yang digunakan } \\
\text { oleh SOM pada Subdit Pengembangan } \\
\text { Sistem Informasi. Tujuan dari soP ini } \\
\text { adalah untuk memberikan panduan } \\
\text { dalam melakukan aktivitas permintaan } \\
\text { perawatan SIM yang disampaikan oleh } \\
\text { pelanggan/unit. }\end{array}$ & \multirow{3}{*}{\multicolumn{2}{|c|}{$\begin{array}{l}\text { Daftar Pelaksana: } \\
\text { - Pelanggan/Unit } \\
\text { - Staf Service Desk } \\
\text { - PIC (Person-in-Charge) / Penanggung Jawab } \\
\text { Kualifikasi Pelaksana } \\
\text { - Memiliki kemampuan teknis yang baik } \\
\text { - Memiliki kemampuan interpersonal yang baik } \\
\text { - Memiliki pemahaman terhadap alur permintaan } \\
\text { perawatan SIM }\end{array}$}} \\
\hline KETERKAITAN & & \\
\hline SOP Perbaikan SIM & & \\
\hline REFERENSI & \multicolumn{2}{|c|}{ PERLENGKAPAN/PERSYARATAN } \\
\hline I5O/IEC 14764:2006 & \multicolumn{2}{|c|}{ 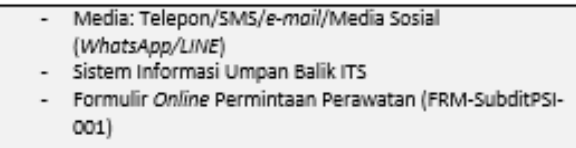 } \\
\hline PERINGATAN & \multicolumn{2}{|c|}{ PENCATATAN DAN PENDATAAN } \\
\hline $\begin{array}{l}\text { Jika SOP ini tidak dijalankan maka } \\
\text { penanganan terkait perawatan SIM } \\
\text { tertunda atau tidak dapat dilakukan. }\end{array}$ & \multicolumn{2}{|c|}{$\begin{array}{l}\text { Mencatat identitas pelanggan/unit } \\
\text { Mencatat detail informasi terkait permintaan perawatan } \\
\text { yang diperoleh dari tiket atau laporan langsung dari } \\
\text { pelanggan. }\end{array}$} \\
\hline
\end{tabular}

Gambar 3 Deskripsi dan Informasi Prosedur Permintaan Perawatan SIM 


\begin{tabular}{|c|c|c|c|c|c|c|c|}
\hline \multicolumn{8}{|c|}{ ALUR TAHAPAN PERMINTAAN PERAWATAN SISTEM INFORMASI MANAJEMEN } \\
\hline \multirow{2}{*}{\multicolumn{2}{|c|}{$\begin{array}{l}\text { AKTIVITAS PROSEDUR } \\
\text { Permintaan Perawatan SIM }\end{array}$}} & \multicolumn{4}{|c|}{ Pelaksana } & \multicolumn{2}{|c|}{ Mutu Baku } \\
\hline & & Pelanggan/Unit & Service Desk & Kasubdit & PIC & Syarat & Waktu \\
\hline 1. & $\begin{array}{l}\text { Mendapatkan } \\
\text { permasalahan pada saat } \\
\text { menggunakan SIM dan } \\
\text { menyusun laporan. }\end{array}$ & & & & & $\begin{array}{l}\text { Perawatan dilakukan } \\
\text { terhadap permasalahan } \\
\text { seperti SIM error, tidak } \\
\text { berfungsinya fitur pada } \\
\text { SIM, tidak adanya fitur } \\
\text { yang dibutuhkan oleh } \\
\text { pelanggan/unit pada } \\
\text { SIM, atau } \\
\text { permasalahan lain } \\
\text { berkaitan pada Subdit } \\
\text { Pengembangan SI. }\end{array}$ & \pm 1 menit \\
\hline 2. & $\begin{array}{l}\text { Memberikan laporan } \\
\text { permintaan perawatan. } \\
\text { - Apabila melaporkan } \\
\text { melalui service desk } \\
\text { melalui Sistem } \\
\text { Informasi Umpan Balik, } \\
\text { lakukan aktivitas no. } 3 \text {. } \\
\text { - Apabila melaporkan } \\
\text { langsung ke Kasubdit } \\
\text { Pengembangan SI, } \\
\text { lakukan aktivitas no. } 8 \text {. }\end{array}$ & {$[3$} & & 8 & & $\begin{array}{l}\text { Service Desk } \\
\text { memastikan Sistem } \\
\text { Informasi Umpan } \\
\text { Balik ITS } \\
\text { (www.umpanbalik.i } \\
\text { ts.ac.id) dapat } \\
\text { diakses } 24 \text { jam, } \\
\text { terutama pada jam } \\
\text { kerja. } \\
\text { - Laporan secara } \\
\text { langsung dapat } \\
\text { melalui } \\
\text { telepon/SMS/ e- } \\
\text { mail/media sosial } \\
\text { (WhotsApp/LINE) } \\
\end{array}$ & \pm 3 menit \\
\hline
\end{tabular}

Gambar 4 Alur Prosedur Perawatan SIM

Untuk dokumen terkait formulir permintaan yang dihasilkan, terdapat dua macam versi yang dibuat, yaitu secara hard copy seperti yang ditunjukkan pada Gambar 5 dan formulir secara online menggunakan aplikasi Form pada Office 365, yang didasarkan dari keinginan Subdit PSI untuk memudahkan staf dalam melakukan pencatatan/dokumentasi ketika melaksanakan aktivitas perawatan, seperti yang ditunjukkan pada Gambar 6 . Dari dokumen SOP yang telah disusun, selanjutnya dilakukan proses verifikasi dan validasi dokumen terhadap Subdit PSI DPTSI ITS Surabaya. 


\begin{tabular}{|c|c|c|c|c|}
\hline \multirow{4}{*}{\multicolumn{2}{|c|}{$\begin{array}{l}\text { INSTITUT TEKNOLOGI SEPULUH NOPEMBER } \\
\text { DIREKTORAT PENGEMBANGAN } \\
\text { TEKNOLOGI DAN SISTEM INFORMASI }\end{array}$}} & \multicolumn{3}{|c|}{$\begin{array}{c}\text { FORMULIR LAPORAN } \\
\text { PERMINTAAN PERAWATAN } \\
\text { (FRM-SubditPSI-001-Bln-Thn-)CX) }\end{array}$} \\
\hline & & \multicolumn{2}{|c|}{$\begin{array}{l}\text { No Tiket } \\
\text { Permintaan }\end{array}$} & $\begin{array}{l}\text { (di........... (Contoh: 6457] } \\
\text { (disi jila melalui Service Desk) }\end{array}$ \\
\hline & & \multicolumn{2}{|c|}{ Hari/Tanggal } & 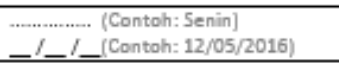 \\
\hline & & \multicolumn{2}{|c|}{ Waktu } & - - WiB (Contoh: 10.45) \\
\hline \multicolumn{5}{|c|}{ DATA PELANGGAN/UNIT } \\
\hline Nama & \multicolumn{4}{|c|}{$\begin{array}{l}\text { (Menuliskan nama pelanggan/unit yang mengajukan permintaan perbaikan. } \\
\text { Contoh: Biro Keuangan Sarana dan Prasarana) }\end{array}$} \\
\hline No. HP & \multicolumn{4}{|c|}{ (Menuliskan nomor HP pelangEan/unit. Contoh: +6282257524938) } \\
\hline E-mail & \multicolumn{4}{|c|}{ (Menuliskan e-mail pelanggan, mengEunakan domain @its.acidid) } \\
\hline \multicolumn{5}{|c|}{ KETERANGAN PERMINTAAN } \\
\hline $\begin{array}{l}\text { Deskripsi } \\
\text { Permintaan } \\
\text { Perawatan }\end{array}$ & \multicolumn{4}{|c|}{$\begin{array}{l}\text { (Menuliskan deskripsi permintaan perawatan dari laporan yang disampaikan oleh } \\
\text { pelanggan/unit melalui Service Desk atau Staf Subdit Pengembangan Sistem Informasi, } \\
\text { secara lengkap dan detail } \\
\text { Contoh: Tidak bisa mengakses modul AngEaran pada SIM Keuangan, yang ditampilkan } \\
\text { halaman kosong.) }\end{array}$} \\
\hline $\begin{array}{l}\text { Jenis Perawatan/ } \\
\text { Perbaikan }\end{array}$ & \multicolumn{4}{|c|}{$\begin{array}{l}\text { Perbaikan Error pada SIM } \\
\bigcirc \text { Penambahan Fitur pada SIM } \\
\text { (Centang vane dipilih) } \\
\text { (Cent........ (Tuliskan jila diluar pilihan yang ada) }\end{array}$} \\
\hline $\begin{array}{l}\text { Sistem Informasi } \\
\text { Manajemen (5ıM) }\end{array}$ & \multicolumn{2}{|c|}{$\begin{array}{l}\text { O SIM AKADEMIK } \\
\bigcirc \text { SIM KEPEGAWAIAN } \\
\text { SIM KEUANGAN } \\
\text { SIM _........... } \\
\text { (Tulisklan jika diluar pilihan yang ada) } \\
\text { (Centang yang dipilih) }\end{array}$} & Prioritas & $\begin{array}{l}\text { BIASA } \\
\text { MEDIUM } \\
\text { M MENDESAK } \\
\text { (Tuliskan jika diluar pilihan yang ada) } \\
\text { (Centang yang dipilih) }\end{array}$ \\
\hline \multicolumn{5}{|l|}{ PELAIKSANA } \\
\hline Nama PIC & \multicolumn{4}{|c|}{ (Menuliskan nama PIC penangEung jawab perawatan. Contoh: Sri Lestari) } \\
\hline & $\overline{\mathrm{DI}}$ & lan Nam & & \\
\hline
\end{tabular}

Gambar 5 Formulir Hard Copy Laporan Permintaan Perawatan SIM

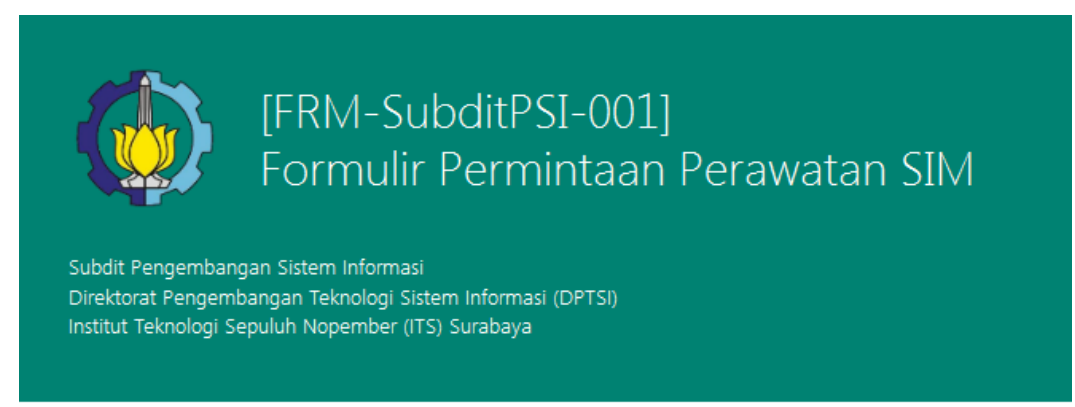

Hai 5212100052@mahasiswa.integra.its.ac.id, ketika Anda mengirim formulir ini, pemilik dapat melihat nama dan alamat email Anda.

* Wajib diisi

1. Tanggal Permintaan Perawatan Masuk *

Pilih tanggal laporan permintaan perawatan yang diterima oleh Service Desk atau Staf Subdit Pengembangan Sistem

Informasi.

Contoh: 15/01/2017

Gambar 6 Formulir Online Laporan Permintaan Perawatan SIM 


\subsection{Verifikasi dan Validasi Dokumen SOP Perawatan SIM}

Dari hasil dokumen SOP yang telah disusun, kemudian dilakukan verifikasi terhadap dokumen untuk memastikan bahwa tidak terdapat kesalahan pada aktivitas dalam tiap-tiap prosedur, serta formulir yang telah dibuat. Verifikasi dilakukan melalui proses wawancara dengan Subdit PSI DPTSI ITS Surabaya. Dari hasil verifikasi SOP, diketahui ada beberapa perbaikan dokumen SOP yang harus dilakukan, terkait dengan:

1) Penambahan pelaksana dan aktivitas pada prosedur permintaan perawatan SIM dan pemantauan SIM

2) Perbaikan urutan nomor prosedur pada prosedur perbaikan SIM

3) Penambahan deskripsi contoh pada tiap-tiap kolom pertanyaan di formulir (baik secara hardcopy maupun online) untuk memudahkan staf yang menjadi PIC dalam pelaksanaan aktivitas perawatan SIM supaya informasi yang disampaikan melalui formulir sesuai dengan harapan dari Subdit PSI.

Setelah revisi pada dokumen SOP dilakukan, kemudian dilakukan validasi terhadap dokumen SOP. Proses validasi berlangsung dengan melakukan simulasi aktivitas perawatan SIM dari skenario yang disusun oleh peneliti, untuk memastikan bahwa SOP dapat diimplementasikan oleh pengguna nantinya, yaitu Subdit PSI DPTSI ITS Surabaya. Dari hasil validasi yang dilakukan, diperoleh hasil bahwa staf Subdit PSI dapat mengoperasikan SOP dengan tepat. Dokumen SOP juga jelas untuk dipahami dan sesuai dengan kebutuhan dari Subdit PSI, namun masih diperlukan beberapa perbaikan untuk lebih mengoptimalkan penggunaan formulir dan juga menyesuaikan kebutuhan dari Subdit PSI.

\section{Kesimpulan}

Berikut adalah simpulan dan saran yang dapat diberikan dari hasil penelitian ini.

\subsection{Simpulan}

Hasil analisis gap yang dilakukan menunjukkan bahwa terjadi kesenjangan dimana hampir keseluruhan proses perawatan SIM yang dilakukan oleh DPTSI ITS Surabaya belum sepenuhnya sesuai dengan aktivitas yang terdapat dalam best practice ISO/IEC 14764:2006 terkait perawatan perangkat lunak dan aktivitas Backup dan Pemantauan pada IT Operation Management Function ITILv3. Ketidaksesuaian tersebut disebabkan karena pada awalnya Subdit Pengembangan Sistem Informasi (PSI) DPTSI ITS Surabaya tidak memiliki standar yang digunakan sebagai acuan dalam melaksanakan proses perawatan SIM sehingga banyak aktivitas yang tidak dilaksanakan dengan baik, terutama masalah tentang aktivitas dokumentasi yang selama ini tidak pernah dilakukan. Oleh karena itu, dibutuhkan perancangan prosedur sebagai panduan untuk melaksanakan rangkaian proses perawatan SIM dalam bentuk dokumen Standard Operating Procedure (SOP). Dokumen SOP tersebut terdiri dari alur prosedur, dengan penggunaan formulir (baik secara offline maupun online) yang semakin memudahkan staf Subdit PSI untuk melakukan dokumentasi terhadap aktivitas perawatan SIM.

Berdasarkan hasil analisis GAP, didapatkan usulan pembuatan 6 prosedur, yaitu: Prosedur Permintaan Perawatan SIM, Prosedur Perbaikan SIM, Prosedur Migrasi SIM, Prosedur Pemberhentian SIM, Prosedur Backup Database dan Sistem Informasi, serta Prosedur Pemantauan SIM. Keseluruhan isi dokumen SOP dibukukan secara terpisah menjadi sebuah dokumen produk berjudul Dokumen Standard Operating Procedure (SOP) Perawatan Sistem Informasi Manajemen (SIM) Direktorat Pengembangan Teknologi dan Sistem Informasi (DPTSI) ITS Surabaya. Hasil dari kedua pengujian SOP (melalui verifikasi dan validasi) tersebut menunjukkan bahwa meskipun secara keseluruhan alur prosedur dan dokumen sudah sesuai, untuk kedepannya ada beberapa bagian dari dokumen yang perlu dibenahi dan disesuaikan dengan kondisi yang ada di Subdit PSI DPTSI ITS Surabaya. Setelah revisi selesai, dokumen tersebut telah sesuai dengan kebutuhan dan dapat diterapkan. 


\subsection{Saran}

Saran yang dapat diberikan untuk pihak pengelola layanan DPTSI ITS Surabaya dan untuk penelitian selanjutnya adalah:

1) Penulis menyarankan agar dokumen SOP yang telah diuji bisa benar-benar diterapkan dengan baik. Hal pertama yang dapat dilakukan Subdit PSI DPTSI ITS Surabaya adalah melakukan rencana penerapan dan melakukan sosialisasi pada seluruh pelaksana SOP, terutama apabila terjadi pergantian staf akibat berakhirnya masa jabatan.

2) Perlu adanya evaluasi dalam 6 bulan sekali terhadap pelaksanaan SOP Perawatan SIM, sehingga diketahui apakah staf Subdit PSI DPTSI ITS Surabaya telah melaksanakan proses perawatan SIM sesuai dengan SOP, dan apakah ada kendala atau permasalahan lain yang menyebabkan perlunya pengubahan prosedur dalam perawatan SIM yang ada di SOP.

3) Penelitian ini hanya sebatas pembuatan dokumen SOP hingga proses pengujian tanpa memantau pengimplementasian SOP tersebut dan pengaruhnya bagi proses bisnis organisasi. Untuk penelitian selanjutnya, dapat dilakukan pengujian dan evaluasi keefektifan dokumen SOP ini terhadap proses perawatan SIM yang dilakukan oleh Subdit PSI DPTSI ITS Surabaya.

4) Penelitian ini hanya fokus pada aktivitas-aktivitas pada software maintenance, yang mencakup juga proses backup. Untuk penelitian selanjutnya bisa dikembangkan lagi dengan menambahkan aktivitas yang terkait dengan perawatan terhadap infrastruktur SIM.

5) Untuk penelitian selanjutnya dapat membuat instruksi kerja sebagai bentuk penyempurnaan dokumen SOP Perawatan SIM.

6) Metode analisis kesenjangan yang digunakan dalam penelitian ini masih bersifat sederhana. Untuk penelitian dengan topik yang sama, dapat dikembangkan dengan menggunakan metode gap analysis lain yang lebih detil dalam menilai kesesuaian proses.

Untuk penelitian selanjutnya dapat menggunakan standar acuan yang lebih detail terkait aktivitas backup, seperti ISO/IEC 27002:2013.

\section{Daftar Rujukan}

[1] ISO, ISO/IEC 14764:2006 - Software Engineering-Software Life Cycle Processes - Maintenance, ISO Standard Catalogue, 2006.

[2] DPTSI, "Direktorat Pengembangan Teknologi dan Sistem Informasi ITS Surabaya," ITS, 2013. [Online]. Available: http://dptsi.its.ac.id/. [Accessed 29 November 2016].

[3] U. L. Yuhana, Interviewee, Sistem Informasi Manajemen dilingkup ITS. [Interview]. 6 Juli 2015.

[4] Office of Goverment Commerce (OCG), Service Operation ITIL, United Kingdom: The Stationery Office, 2007.

[5] P. Setiawan, "10 Pengertian Sistem Informasi Manajemen Menurut Ahli dan Tujuannya," Guru Pendidikan, 23 Maret 2015. [Online]. Available: http://www.gurupendidikan.com/10-pengertian-sistem-informasi-manajemen-menurut-ahli-dantujuannya/. [Accessed 20 Oktober 2015].

[6] S. D. Haes and W. V. Grembergen, "IT Governance and Its Mechanisms," Information Systems Control Journal, 2004.

[7] Boundless, "The GAP Model," Boundless.com, Anline]. https://www.boundless.com/marketing/textbooks/36/services-marketing-6/service-quality-51/the-gap-model-2544140/issues/new/. [Accessed 30 Juli 2015].

[8] Peraturan Menteri, "Pedoman Penyusunan Standar Operasional Prosedur Administrasi Pemerintah," Kementerian Pendayagunaan Aparatur Negara dan Reformasi Birokrasi RI Tahun 2012, 2012. [Online]. Available: http://www.kopertis3.or.id/html/wp-content/uploads/2011/04/permenpan2012_035.pdf. [Accessed Agustus 102015 ].

[9] M. Farid, T. D. Susanto and A. S. Nisafani, "Pembuatan SOP Menurut PERMENPAN No.52 Tahun 2011 dengan Best Practice COBIT 5 dan ITIL V3," in SESINDO, Surabaya, 2013.

[10] I. U. Ataina, Pembuatan Standar Operasional Prosedur (SOP) Manajemen Akses Sistem Informasi Manajemen (SIM) Berdasarkan Kerangka Kerja ITIL V3 dan ISO 27002 (Studi Kasus: Institut Teknologi Sepuluh Nopember), Surabaya: ITS, 2015. 
[11] A. C. Puspitaningrum, Pembuatan Standard Operating Procedure (SOP) Pengembangan Sistem Informasi Manajemen (SIM) Berdasarkan Analisis Kesenjangan dengan Menggunakan Kerangka Kerja COBIT 5 dan ITILv3. (Studi Kasus: Lembaga Pengembangan Teknologi Sistem Informasi ITS Surabaya), Surabaya: ITS, 2015.

[12] A. Rachmi, T. D. Susanto and A. Herdiyanti, "Pembuatan Standard Operating Procedure (SOP) Service Desk Berdasarkan Kerangka Kerja ITIL V3 dengan Menggunakan Metode Analisis GAP Layanan (Studi Kasus: PT XYZ, Tangerang)," in SESINDO, Surabaya, 2014.

[13] S. W. Restiana, Pembuatan Standard Operating Procedure (SOP) Layanan TI Berdasarkan Gap Analysis dan ITIL 2011 Level Service Operation pada Jurusan Sistem Informasi ITS, Surabaya: ITS, 2015. 